Article title: Service Quality Satisfaction: Perceptions of Ghanaian Higher Education Students Learning at a Distance Authors: samuel amponsah[1], Boadi Agyekum[2]

Affiliations: Department of Distance Education, School of Continuing and Distance Education, College of Education, University of Ghana, P. O. Box LG 31, Legon-Accra, Ghana[1], University of Ghana Learning Centres, School of Continuing and Distance Education, College of Education, University of Ghana, P. O. Box LG 31, Legon-Accra, Ghana[2]

Orcid ids: 0000-0002-4303-4863[1], 0000-0003-2602-1718[2]

Contact e-mail: samponsah@ug.edu.gh

License information: This work has been published open access under Creative Commons Attribution License http://creativecommons.org/licenses/by/4.0/, which permits unrestricted use, distribution, and reproduction in any medium, provided the original work is properly cited. Conditions, terms of use and publishing policy can be found at https://www.scienceopen.com/.

Preprint statement: This article is a preprint and has not been peer-reviewed, under consideration and submitted to UnisaRxiv for open peer review.

Funder: N/A

DOI: 10.25159/UnisaRxiv/000008.v1

Preprint first posted online: 30 April 2021

Keywords: higher education, learning centres, service quality, SERVQUAL Theory 


\section{Service Quality Satisfaction: Perceptions of Ghanaian Higher Education Students Learning at a Distance}

\author{
Samuel Amponsah \\ https://orcid.org/0000-0002-4303-4863 \\ School of Continuing and Distance \\ Education, University of Ghana \\ samponsah@ug.edu.gh
}

\author{
Boadi Agyekum \\ https://orcid.org/0000-0003-2602-1718 \\ School of Continuing and Distance \\ Education, University of Ghana
}

\section{Abstract}

Assessing students' satisfaction of service quality is vital to educational service providers. This qualitative study hence employed the SERVQUAL Theory to explore the perspectives of 30 distance learning students on the quality of services provided at the University of Ghana Learning Centres. The participants were purposively selected and engaged in in-depth qualitative interviews through a semi-structured interview guide. Our findings revealed varied satisfaction levels with the five dimensions of quality of service: reliability, assurance, responsiveness, tangibility, and empathy. The findings revealed that students' perceptions of the tangibility and empathy dimensions were negative. We thus advocate leveraging the three dimensions perceived to be satisfying among students while ensuring improvements in the two other dimensions that elicited no satisfaction. Consequently, we offer recommendations framed by UNESCO that may be of interest to providers and managers of distance education programmes in similar learning centres.

Keywords: higher education, learning centres, service quality, SERVQUAL Theory

\section{Introduction}

Recent studies on service quality in higher education (HE) have begun to explore student satisfaction regarding a number of factors including quality of academic staff, infrastructure, support services, and other conditions as fundamental and important aspects of educational excellence (Agyekum 2020; Lodesso et al. 2018). This work follows this stream of research focusing on distance education (DE). The main goal is to explore service provision in DE in a developing society and to explore its relationship with satisfaction. This topic has seldom been dealt with in a fledgeling economy, and most existing research fails to connect different forms of service quality.

The concept of service quality has been in the educational realm in relation to the quality of education (Lodesso et al. 2018). Others have referred to the need for efforts to infuse equitable service quality improvement initiatives to enhance quality in all aspects of the DE programme. Malik, Danish, and Usman (2010) define service quality in terms of 
stakeholders or students' perceptions of service once exposed to a specific service, including academic or administrative services at the institution. Student satisfaction of services is a distributive approach to academic affairs that, if positively evaluated, would mean those who are excluded can feel the change in the academic environment and supported and included so that they can prosper and realise their full potential, and feel that they can aspire to every aspect of society.

The current study is also motivated by other considerations. First, although people have access to the Internet and other resources, the DE in Ghanaian universities is still not perfect and most students prefer traditional systems to DE (Kotoua, Ilkan, and Kilic 2015). A university's distance learning centre is an excellent context to assess whether this process actually occurs since enrolment to DE programmes has increased considerably in recent years.

Second, the nature of DE in developing countries is fraught with a number of challenges, such as a lack of infrastructure and support services. Many students pursuing HE programmes by DE mode in Ghana face challenges, making it difficult to complete the four-year degree programmes on time (Biney 2021).

Third, there are relevant differences in perception of quality support services and opportunities among Ghanaian DE students from different learning centres (LCs) and levels of study (Agyekum 2020). In this context, the aims of the present study are to: (a) define DE students' perception of service quality; (b) assess the DE students' satisfaction with the service quality improvements in the LCs; and (c) explore which dimensions of service quality are stronger and need to be promoted in order to improve the service quality among DE students in the LCs.

\section{Framing Students' Perspectives of Service Quality through SERVQUAL Theory}

Cheng and Rashid (2013) documented that organisations which fail to provide quality products and services might lose their customers to competitors. It is therefore imperative for institutions that seek to thrive in the turbulent environment to find farsighted ways of assessing and improving their service quality to satisfy their clients. Parasuraman, Zeithaml and Berry developed the SERVQUAL Theory in 1988 and modified it in 1991 as a multi-item or multidimensional scale for assessing customer perceptions of the quality of services organisations provide for them. The theory has been applied by many researchers (Al-Jazzazi and Sultan 2017; Cheng and Rashid 2013; George and Kumar 2014) notably in the banking sector. Given that the philosophy of $\mathrm{DE}$ is to give access and lifelong learning opportunities to potential students who could not access main campuses, there is a need to ensure that those opportunities provided are satisfying. We therefore adopted the modified SERVQUAL Theory as the lens to understand the perceptions of University of Ghana (UG) DE students on the service quality of the programme. 
Rauch et al. (2015) define service quality as the way in which companies meet or exceed customer expectations. Mauri, Minazzi and Muccio (2013) indicate that consumers assess and perceive service quality according to the five essential constructs in Parasuraman, Zeithaml and Berry's (1991) modified SERVQUAL Theory, namely, reliability, assurance, responsiveness, tangibility, and empathy.

First, Parasuraman, Zeithaml and Berry (1991) note that reliability depicts an institution's ability to perform required services dependably and accurately for the first time. They also note that not only should organisations do things right the first time but they must also strive to fulfil promises and pay attention to results. Ennew, Waite and Waite (2013) reveal that reliability could be regarded as the extent to which customers can rely on the service promised by the organisation. In essence, service quality should focus on the past, present and future outcomes.

Assurance reflects the ability of staff to provide friendly, confidential, courteous and competent services that has a positive impact on their clients' knowledge, skills, attitudes and behaviour. Pakurár et al. (2019) detail that listening to clients provides them with the assurance of getting their money and time's worth from service providers. The ability of staff to transfer confidence, trust and satisfaction to their clients, regardless of their educational level, age and nationality, is central to the element of assurance.

Closely linked to the foregoing construct is responsiveness, which Parasuraman, Zeithaml and Berry (1994) highlight as the willingness of employees to give clients realtime information. Employees thus give clients their undivided attention, promote their institution's services and give personalised responses to clients. Yarimoglu (2014) sees responsiveness as access to services and emphasises that there should be accessibility through real-time responses, operation hours, and that the location of the institution should be convenient to clients. Consequently, Gonu and Agyepong $(2016,12)$ state that "this dimension emphasises attentiveness and promptness in dealing with customer requests, questions, complaints, and problems".

Tangibles is another essential construct of the modified SERVQUAL Theory which Parasuraman, Zeithaml and Berry (1994) consider the physical facilities of the institution. These facilities consist of (sophisticated) equipment, personnel, communications materials and machines for enhancing speed and efficiency of transactions (Ananth, Ramesh, and Prabaharan 2010; Pakurár et al. 2019). Ananth, Ramesh and Prabaharan (2010) further identified the attractive ambience of institutions to have an impact on customer satisfaction. In the context of DE, Zhou et al. (2017) argue for a mix of digital and traditional media for enhancing tangibles to support teaching and to optimise learning.

Lastly, Parasuraman, Zeithaml and Berry (1994) reveal that giving clients the feeling of being unique and special is at the heart of empathy. Pakurár et al. (2019) identify paying 
personal attention to clients as important in the context of empathy as they will feel prioritised. For institutions to operate within the ambit of empathy, Parasuraman, Zeithaml and Berry (1991) call for the need to understand customer expectations better than competitors. The authors believe such understanding helps to provide tailor-made care and attention to increase clients' satisfaction levels. Ananth, Ramesh and Prabaharan (2010) call for individualised attention and a better understanding of customer's specific needs in this regard.

Although the modified SERVQUAL Theory has been used extensively to measure service quality and satisfaction mainly in the banking sector (Pakurár et al. 2019), it is important to note that the SERVQUAL Theory is an appropriate assessment tool for measuring service quality perceptions of clients generally. A few studies on DE in the Ghanaian context have been cited to use the SERVQUAL Theory (Eshun, Badu, and Korwu 2018; Gonu and Agyepong 2016). Given the gap identified and the fact that the modified SERVQUAL model has proven to be an effective tool to assess service quality globally, we deem it appropriate to assess the dimensions of the UG DE service quality from students' perspectives.

\section{Methodology}

The selection of the UG DE programme represents purposive sampling to understand students' perspectives of the service quality of the programme. The UG operates a blended mode and operates in 11 LCs across the country (UG 2021). In-depth qualitative interviews were conducted with 30 participants of the UG DE programme who engage in face-to-face tutorials during weekends at the UG LCs. The participants included 15 participants at each learning centre (a total of 17 female and 13 male students). The recruitment period was from August to November 2020. The interviews were conducted by both authors and lasted approximately 35 minutes, with all interviews conducted in English. A semi-structured interview guide was used that provided an opportunity for interactive discussions which explored experiences and perceptions from the perspectives of the participants using their meanings and interpretations.

Purposive sampling was used to recruit participants for the in-depth interviews. The participants included DE students from both Accra and Tema LCs. These LCs receive approximately 90 per cent of DE students to the UG annually (UG 2020). A hermeneutic interpretivist phenomenological approach was employed to inductively explore the participants' perspectives of service quality, which entailed the use of a hermeneutic circle to intersubjectively understand the many meanings involved (Newberry 2012). This process required numerous readings of the interview transcripts, both pre-and postcoding, and conducting an analysis that aimed to identify meaning units, condensed meaning units and analytical (sub)themes (McAuley 2004). The interviews were transcribed and the data coded and analysed from which descriptive feedback reports were developed. 


\section{Findings}

Overall, the participants described the five categories of service quality, namely, reliability, assurance, responsiveness, tangibility and empathy. The rest of this section describes these categories in detail and provides excerpts from the participants' testimonies, as appropriate. For DE students who attend classes in the LCs, securing quality services is often considered to be the most difficult challenge.

\section{Reliability}

Concerning the reliability dimension, the participants had mixed beliefs about the ease with which they could access support services in the LCs. The majority of the participants believed that their access to support services increased in the LCs:

I think the University is doing its best and we are comfortable. This is because we are getting all the support we need from the University.

Even though those of us in Tema do not have access to well-structured facilities, our management try as much as possible to ensure that our needs are met halfway.

However, a number of participants expressed concern over the challenges associated with accessing certain types of physical facility or service, such as poor infrastructure and tutors' commitment. For instance, some found it challenging to be active in the LCs, particularly for those who need regular assistance from tutors.

There are times when tutors do not show up and there is also the indiscriminate cancellation of tutorials.

Although the participants expressed views on the issues concerning the UG DE programme that were consistent with previous studies (Agyekum 2020), they did not necessarily translate these views into a decline in DE programmes. Although similar challenges for success in HE are reported in regular student populations (Kaatrakoski, Littlejohn, and Hood 2017), the experiences of DE students are complicated by the dynamic interplay of HE challenges that play out in the distance mode of education. More could therefore be done to fulfil the promised and actual services (Ennew, Waite and Waite 2013; Parasuraman, Zeithaml, and Berry 1991) provided by the UG DE providers to reduce the sources of vulnerability to HE that were rooted in challenges associated with DE programmes.

\section{Assurance}

It is interesting to note that when asked to identify factors that contribute to their educational status change (an improvement), none of the participants identified factors related to access to specific quality services. The factors identified were varied among those noting educational improvement and a decline. Those participants who believed 
their education had improved attributed this positive change to what they perceived as a superior DE environment.

Distance education has given some of us voices to speak. Not only that but it is gradually building our self-esteem as well. DE has given equal opportunity and certificates to those of us who couldn't make it after high school.

I have gained the experience of being independent in terms of understanding the learning materials rather than depending on a Tutor or Lecturer. I am a worker and a single mother. Distance learning has helped me organize my home on weekends and work during the weekdays.

On the other hand, some participants identified the cost of enrolling in DE programmes as a factor that could have a potential negative impact on DE programmes.

Distance education is very expensive, especially for those of us who are not working full-time and without support from our families. It's a full fee-paying programme with no financial support from the University.

These findings are also significant given the growing body of research on DE environments. These environments promote competence, confidence and trust among learners which invariably depict the positive work ethic of the DE employees at the LCs (Pakurár et al. 2019; Parasuraman, Zeithaml, and Berry 1994). However, some participants discussed the costs of enrolment as challenging and a stressful part of the $\mathrm{DE}$ programme. The role of $\mathrm{DE}$ in promoting inclusion or exclusion in higher education may thus be much more complex than what has been suggested in the HE literature.

\section{Responsiveness}

The optimism of many of the participants to be successful in the DE programme seemed to be nurtured by the commitment of the staff and some DE officials to help them willingly, believing that with a little bit more support they would be successful.

They are doing their best and it is enough for now. However, if additional support could be extended, we will be grateful.

Our Centre Heads and their staff are ever ready to respond to any call for clarifications.

They may need to up their level of commitment. As compared to what happens at the main campus, our support staff lag behind. There is indeed more room for improvement for them.

The preceding narratives largely show that service providers at the LCs are responsive to the needs of the students in line with what has been recorded in literature given the responsiveness dimension (Gonu and Agyepong 2016; Parasuraman, Zeithaml, and Berry 1994). These authors believe responsiveness contribute to the satisfaction of 
clients and despite the shortfalls derived from the responses of the participants. Despite some negative perceptions, the majority of the participants felt that the UG DE programme contributed positively to improving their academic status. Similarly, the participants shared mixed views about the ease with which service providers willingly help them but thought they could still improve on their responsiveness.

\section{Tangibility}

According to Parasuraman, Zeithaml and Berry (1994), the tangible dimension of the service quality refers to the surroundings, physical facilities and equipment used in the delivery of services (for example, in the LCs) and the appearance of the personnel. DE students regard aspects of the tangibles in the LCs as insufficient and poor in quality. Two of the participants remarked:

We aren't getting the full package of the DE programme. Our libraries and ICT Labs are closed during lecture hours, poor and sometimes incomplete lecture videos and slides and others.

Learning and teaching is not much effective for students due to poor facilities at the Centre. We seem to compromise since we don't have access to the main lecturers except during revision periods.

Overall, the quality of support services is ideal for framing student success and persistence for under-represented students. Current research on satisfaction and quality of service (see Rajabalee and Santally 2020) indicates a lack of attention to students from under-represented groups, particularly DE students. In this study, the kind of media for optimising teaching and learning (Zhou et al. 2017) seems absent from the LCs. The challenge with using quality of service as the ultimate measure for student satisfaction is that "satisfaction can mean something completely different to student groups who have been historically marginalized in higher education" (Hurtado and Carter 1997).

\section{Empathy}

Empathy occurs when DE students are provided with the individual care and attention they need or when they do have equitable access to learning and teaching services because of their status as DE students (Lodesso et al. 2018; Parasuraman, Zeithaml, and Berry 1994). The participants reported feeling misunderstood, discriminated against, and excluded from many aspects of the services and academic life at the UG.

You do not get all services at the Centre, most times you will be directed to the main campus. Currently, we are in level 300 and we have not gotten any explanation on what courses to choose or drop.

Being a DE student is too stressful and exhausting in the sense that the institution does not put much effort or consideration into the needs of students in this programme. 
The accumulation of this burden together with limited services and resources to support their academic life further diminishes DE students' self-esteem and self-confidence (Vakoufari, Angelaki, and Mavroidis 2014). This runs parallel to the call for identifying students' challenges and providing them with prompt tailor-made attention to increase their satisfaction (Pakurár et al. 2019). It is, however, important to consider that ensuring empathy is a key pillar in service provision as the experiences of DE students are mostly complicated by the dynamic interplay of educational exclusion that plays out in the distance learning mode.

\section{Conclusion and Recommendations}

The UG has not given much recognition to DE students engaged in face-to-face tutorials as a unique student population requiring special structures of distance learning promotion strategies and special arrangements of DE support services. We recommend that DE authorities and policymakers responsible for developing DE support services investigate options for including the distance population among students that qualify for special services. These DE support services may adopt the guidelines proposed by UNESCO (2020), which suggest developing a systematic review or audit of existing institutional policies to take care of the needs of distance learners. Strategic and bold initiatives are required to implement quality of service in more proactive ways that will ensure that all HE students will not experience poor quality services and will have genuine opportunities for success and satisfaction in the university environment.

As DE students continue to make up an increasing percentage of the UG population, it is essential to understand not only the extent to which their status changes with enrolment in DE programmes but also the factors that contribute to quality education. Of equal importance is the need to consider DE students' perceptions of the key services that shape success in DE programmes. Our research has demonstrated the importance of key factors (tangibility and empathy) that have been overlooked without the inclusion of DE students' voices in studies of their education and well-being.

\section{References}

Agyekum, B. 2020. "There is Always this Feelings of Otherness: Exploring the Learning Experience of Distance Education Students in Ghana." International Journal of Higher Education and Research 10 (2): 153-66. https://doi.org/doi:10.7755/ijher170720.08.

Al-Jazzazi, A., and P. Sultan. 2017. "Demographic Differences in Jordanian Bank Service Quality Perceptions.” International Journal of Bank Marketing 35: 275-97. https://doi.org/10.1108/IJBM-07-2016-0091.

Ananth, A. A., R. Ramesh, and B. Prabaharan. 2010. "Service Quality Gap Analysis in Private Sector Bank - A Customer Perspective." Indian Journal of Commercial Management Studies 2: 245-52. 
Biney, I. K. 2021. "McClusky's Theory of Margin and its Implications on Adult Learners in Higher Education Institutions." Journal of Adult and Continuing Education 1-21. https://doi.org/10.1177/1477971421989337.

Cheng, B. L., and M. Z. A. Rashid. 2013. "Service Quality and the Mediating Effect of Corporate Image on the Relationship between Customer Satisfaction and Customer Loyalty in the Malaysian Hotel Industry." Gadjah Mada International Journal of Business 15 (2): 99-112. https://doi.org/10.22146/gamaijb.5474.

Ennew, C., N. Waite, and R. Waite. 2013. "Financial Services Marketing: An International Guide to Principles and Practice." 2nd ed. London: Routledge. https://doi.org/10.4324/9780203521649.

Eshun, E. F., A. K. Badu, and P. Korwu. 2018. "Impact of Service Quality on Students' Satisfaction in a Ghanaian Public Tertiary Institution." International Journal of Learning and Development 8 (3): 97-112. https://doi.org/10.5296/ijld.v8i3.13447.

George, A., and G. G. Kumar. 2014. "Impact of Service Quality Dimensions in Internet Banking on Customer Satisfaction." Decision 41 (1): 73-85. https://doi.org/10.1007/s40622-014-0028-2.

Gonu, E., and G. K. Q. Agyepong. 2016. “Students' Perception about Quality of Distance Education at the University of Cape Coast, Ghana." European Journal of Business and Management 8 (15): 9-20.

Hurtado, S., and D. Carter. 1997. "Effects of College Transition and Perceptions of the Campus Racial Climate on Latino College Students' Sense of Belonging." Sociology of Education 70 (4): 324-45. https://doi.org/10.2307/2673270.

Kaatrakoski, H., A. Littlejohn, and N. Hood. 2017. "Learning Challenges in Higher Education: An Analysis of Contradictions within Open Educational Practice." Higher Education 74: 599-615. https://doi.org/10.1007/s10734-016-0067-z.

Kotoua, S., M. Ilkan, and H. Kilic. 2015. "The Growing of Online Education in Sub-Saharan Africa: Case Study, Ghana.” Procedia - Social and Behavioural Science 191: 2406-11. https://doi.org/10.1016/j.sbs.pro.2015.04.670.

Lodesso, L. S., J.E. van Niekerk, A. C. Jansen, and H. Müller. 2018. "Student Satisfaction regarding Service Quality at Ethiopian Public Higher Education Institutions: A Case Study." Journal of Student Affairs in Africa 6 (2): 51-64. https://doi.org/10.24085/jsaa.v6i2.3309.

Malik, M. E., R. Q. Danish, and A. Usman. 2010. “The Impact of Service Quality on Students' Satisfaction in Higher Education Institutes of Punjab." Journal of Management Research 10 (2). 
Mauri, A. G., R. Minazzi, and S. Muccio. 2013. “A Review of Literature on the Gaps Model on Service Quality: A 3-decades period: 1985-2013.” International Business Research 6 (12): 134. https://doi.org/10.5539/ibr.v6n12p134.

McAuley, J. 2004. "Essential Guide to Qualitative Methods in Organisational Research.” In Hermeneutic Understanding, edited by C. Cassell and G. Symon, 191-202.

Newberry, A. M. 2012. "Social Work and Hermeneutic Phenomenology." Journal of Applied Hermeneutics 2-18. https://doi.org/10.11575/jah.v0i0.53219.

Pakurár, M., H. Haddad, J. Nagy, J. Popp, and J. Oláh. 2019. “The Service Quality Dimensions that Affect Customer Satisfaction in the Jordanian Banking Sector." Sustainability 11 (4): 1113. https://doi.org/10.3390/su11041113.

Parasuraman, A., V. A. Zeithaml, and L. L. Berry. 1991. "Refinement and Reassessment of the SERVQUAL Scale.” Journal of Retailing 67 (4): 420-50.

Parasuraman, A., V. A. Zeithaml, and L. L. Berry. 1994. "Reassessment of Expectations as a Comparison Standard in Measuring Service Quality: Implications for Further Research." Journal of Marketing 58 (1): 111-24.

Rajabalee, Y. B., and M. I. Santally. 2020. "Learner Satisfaction, Engagement and Performances in an Online Module: Implications for Institutional E-Learning Policy." Education and Information Technologies. https://doi.org/10.1007/s10639-020-10375-1.

Rauch, D. A., M. D. Collins, R. D. Nale, and P. B. Barr. 2015. "Measuring Service Quality in Mid-Scale Hotels." International Journal of Contemporary Hospitality Management 27: 87-106. https://doi.org/10.1108/IJCHM-06-2013-0254.

UG (University of Ghana). 2020. “Opening Ceremony for Online Teaching and Learning Training Programme Held.” https://www.ug.edu.gh/news/opening-ceremony-onlineteaching-and-learning-training-programme-held.

UG (University of Ghana). 2021. "Commissioning of George Benneh Graduate Reading Room.” https://www.ug.edu.gh/news/commissioning-george-benneh-graduate-readingroom.

UNESCO. 2020. "Distance Learning Solutions.” 2020.

https://en.unesco.org/covid19/educationresponse/solutions.

Vakoufari, M., C. Angelaki, and I. Mavroidis. 2014. "Self-Esteem and Loneliness as Factors Affecting Distance Learning Students." European Journal of Open, Distance and ELearning 17 (2): 66-79. https://doi.org/10.2478/eurodl-2014-0022.

Yarimoglu, E. K. 2014. “A Review on Dimensions of Service Quality Models.” Journal of Marketing Management 2 (2): 79-93. 
Zhou, F., C. Zhao, Z. Jiang, and L. Wang. 2017. "A Study on the Learning Support Service of Blended Learning under the Environment of Online Open Courses." International Symposium on Educational Technology (ISET), 272-76. https://doi.org/10.1109/ISET.2017.67. 